\title{
Toilet Training Guidebook for the Independent Character in Preschoolers
}

\author{
Kartika Rinakit Adhe, Nurul Khotimah, Safira Wahyu \\ Early Childhood Education Department \\ Universitas Negeri Surabaya \\ Surabaya, Indonesia \\ kartikaadhe@unesa.ac.id
}

\author{
Muchamad Arif Al Ardha \\ Physical Education Department \\ Universitas Negeri Surabaya \\ Surabaya, Indonesia
}

\begin{abstract}
This research develops toilet training guidebook with paired storybook. Specifically, this study aims to (1) to develop a toilet training guidebook on the independence of early childhood, (2) to find out the feasibility of developing a toilet training guidebook on the independence of early childhood, (3) to describe the effectiveness of toilet training guidebooks on children's independence early age. This type of research method Research and Development. The subjects in this study were 40 children in 4 Play Groups in Surabaya. Data collection techniques used were interviews, questionnaires, and observations. Based on the results of the study, proper development that used to guide the teacher in choosing an alternative class setting to be used in his class of $84 \%$. Based on the value of the initial field, the main field trials and operational field trials $(3,4)$ of the 1-4 scale, the toilet training manual on early childhood independence to increase children's knowledge about the way children do proper toilet training. The effectiveness of guidebook toilet training are teacher activities scored $85 \%$ with very good categories. Student activities showed a score of $86 \%$ in the good category. Therefore, this guidebook is worth using to facilitate the toilet training process of early childhood.
\end{abstract}

\section{Keywords—-toilet training; independent character}

\section{INTRODUCTION}

Independent needs to be taught early, this is because children are in the golden age development. Toilet training is one of the basic ways to cultivate discipline early [1]. Early childhood is important to develop the character of discipline for them. Toilet training in children is an attempt to train children to be able to control the urination and defecation [2].

The survey result showed that incidence of still urinating accidentally occurred in about $30 \%$ of children aged 4 years, $10 \%$ of children aged 6 years, $3 \%$ of children aged 12 years and $1 \%$ of children aged 18 years old [3]. Efforts to solve children's problems in self-control when defecating and urinating are by introducing bathrooms and toilets. In the application of parenting parents from an earlier age, starting from the age of 16-18 months can introduce toilet training.

Teaching children to use the right toilet is a process that requires planning, responsibility, consistency, and patience [4]. Teaching the easiest way to excrete is when the child is ready to carry out this stage and the child is able to work together and the consistency of the parent in teaching. If forced before the child is ready, it will potentially invite problems and often cause accidents in toilet use[5]. Urinating and defecation are caused by the inability of children to recognize the urge to go to the toilet, the child has not been able to convey the need to the toilet, the child has not been able to control the muscles of release.

One of the duties of parents as well as teachers on children's growth and development is to form the child's independence to urinate and defecate correctly and can be done independently [6]. Instilling independence in children can be done slowly or gradually in order to develop properly. Factors that influence are the role of the family, in carrying out this role the family is very much influenced by parents' factors. At this time parents must begin to exercise their children's ability to urinate and defecate into the toilet, parents must be patient and understand the child's readiness to start teaching toilet use in a way that parents must consistently deliver children when they want to defecate or urinate into the toilet.

It is important for early childhood and about the rules when urinating and defecating because the child is in the anal stage [7]. The main focus of this stage is on bladder control and defecation. If this stage is traversed it can develop this control causing a sense of accomplishment and independence. Therefore, we need encouragement and motivation from parents and teachers to provide toilet training literacy every day.

The planning process in learning requires the right media so that it can be easily understood by children. The media that is easily used by parents and teachers when learning is a guidebook. The guidebook is a book that contains principles, procedures, basic material descriptions, or learning models used by educators in carrying out their duties and functions as educators [8]. In this study using a guidebook in the form of a story that uses the children's characters.

Good habits in urinating and defecating are very influential in habits that will be carried by children to adulthood. When teaching toilet training incorrectly, it will affect the physical and spiritual health of the child [9]. Physical impact, children can be exposed to dirt while the spiritual impact of children when worshiping is invalid. But on the contrary, if parents or teachers teach about toilet training well, the child will succeed in the toilet training teaching period. However, it is important for children to be taught toilet training as early as possible to have a positive impact on children when they are adults. 
The purposes of this study were to (1) develop a toilet training guidebook for preschoolers, (2) find out the feasibility of the product developed by the guidebook, (3) find out the effectiveness that emerged from the guidebook developed for preschoolers.

\section{METHOD}

\section{A. Research Design}

This study uses Research and Development (R \& D) research with a learning design model, namely the ADDIE (Analysis Design Develop Implement Evaluate) model. The following are the research stage, namely:

\section{Analysis}

The analysis phase is a process of defining what the child will learn. So to know or determine what must be learned, we must do several activities, including a) Perform needs analysis, which is to determine the abilities or competencies that need to be learned by children to improve learning outcomes. b) Perform performance analysis, namely to find out and clarify whether the problem faced requires a solution in the form of making learning devices. After analyzing the problem of the need to develop a new learning model/method, the researcher also needs to analyze the feasibility and requirements for developing new learning. In this analysis, do not let there be a good method design but cannot be applied because of some limitations, for example there is no tool or the teacher is unable to implement it. Analysis of new learning methods needs to be done to determine the feasibility of the learning method is applied.

\section{Design}

In designing the learning, the design phase has similarities to designing teaching and learning activities. This activity is a systematic process that starts from setting learning goals, designing scenarios or teaching and learning activities, designing learning devices, designing learning materials and learning outcome evaluation tools. The design of this learning is still conceptual and will underlie the next development process.

\section{Development}

Development in the ADDIE model contains activities to realize product design. In the design phase, a conceptual framework has been developed for the application of new learning . In the development phase, the conceptual framework is realized to become a product that is ready to be implemented.

\section{Implementation}

At this stage designs and methods have been implemented that have been developed in real situations, namely in the classroom. The main objectives of the implementation phase are as follows: a) Guiding students to achieve learning goals, b) Ensure problem-solving or solutions to overcome student gaps, c) Produce competency output in the form of knowledge, skills, and attitudes needed in students.

\section{Evaluation}

The evaluation was carried out in two forms, namely formative and summative evaluation. Formative evaluation is carried out at the end of each face (weekly) while summative evaluation is carried out after the activity ends in its entirety.

\section{B. Population and Sample}

The population in this study were preschoolers in West Surabaya. Determination of research subjects using purposive sampling. The number of playgroups used is 4 schools. While the number of children used in the trial was 40 children. This trial is intended for children directly, so researchers can observe the results of using guidebook toilet training. The subject of this study used Islamic children because the guidebook was developed based on Islamic rules

\section{Technique Data Collection}

The technique of collecting data in the process of developing guidebook toilet training is a questionnaire to see the feasibility of the product. Observation technique. Also used in this study to collect effectiveness data on products used for preschoolers.

\section{RESULTS AND DISCUSSION}

\section{A. Research Analysis}

The analysis in this study was carried out on the analysis of potential, problems, literature review, competence, instructional objectives, material and child development. From the results of the analysis, the following data are obtained:

\section{Analysis of potential}

There is a development of a guidebook that can attract children to read or just to see. Especially with attractive designs such as making guidebooks combined with cartoon designs. This guidebook uses Islamic rules, so it has the potential to develop children's character in accordance with Islamic teachings.

\section{Analysis of problems}

Problem analysis by a survey conducting about the use of manual media learning. The survey results obtained, that teachers rarely make their own learning media for learning toilet training. This problem makes children have no interest and self-awareness of toilet training.

\section{Analysis of the literature review}

Based on the potential and problems that researchers have tried to find solutions. The solution is based on an analysis of literature studies conducted by researchers. Furthermore, based on the potential and problems, the researcher developed a toilet training guidebook. The development of learning media can improve children learning outcomes and character [10].

\section{Competency analysis}

The researcher analyzes the competencies in material objects that will be developed through the scope of learning.

a) Instructional analysis

The instructional analysis on the development of guidebook toilet training describing and developing 
competencies as indicators that must be achieved. Indicator achievement is a benchmark in the development of guidebook toilet training, seeing the completeness of the process [11].

b) Analysis of children characteristics

According to Piaget's theory of the development of the ability for children to be conveyed that there are stages of the development of the child's ability to learn. According to him, children aged 2-7 years are still in the pre-operational stage at this stage, the child is not able to think abstractly [12]. Therefore, the media will help the message conveyed by the teacher to be more easily accepted by the child.

\section{B. Design Analysis}

The design stage is adjusted to the objectives of the study, including a) Determining the purpose of the guidebook; b) Determine material content in developing guidebooks according to Islamic teachings; c) Designing image images to be presented in a guidebook with Adobe Photoshop; d) Making guidebook characters. Prepare story texts in the guidebook by analyzing the stages of toilet training.
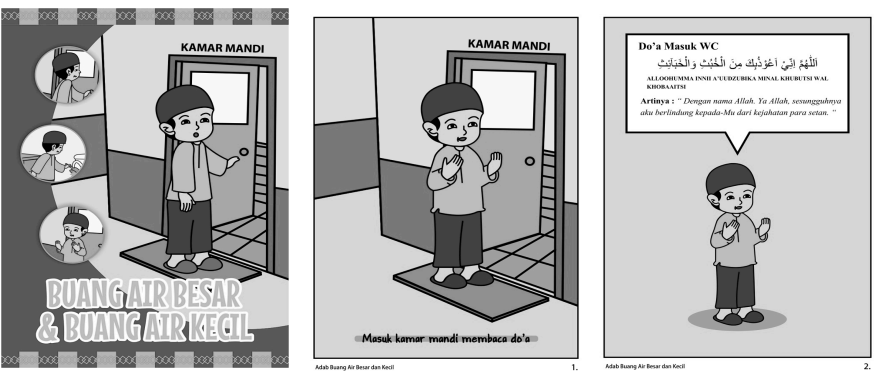

Fig. 1. Designing Guidebook Figure in Islamic Viewpoint

In this design a figure of a boy appears, the first teaching is done with the child praying before entering the toilet. Pray before entering the toilet is important because children need to be accustomed. This prayer is important for the first step.

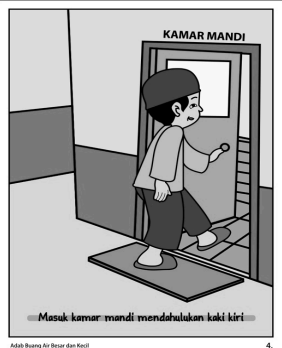

Fig. 2. How to Enter the Toilet in Islamic View Point

In an Islamic viewpoint, the child is taught to enter the bathroom using his left foot, in contrast to entering a house or mosque using his right foot. The bathroom is identical with urine and defecation so it is dirty, Islam teaches if the place like that use the left foot is recommended.
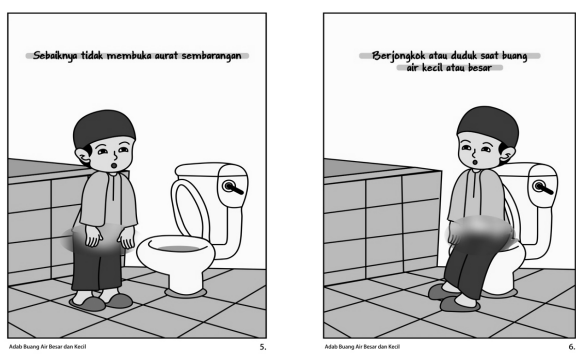

Fig. 3. How to Open Clothes in Islamic View Point

When opening clothes when you want to urinate, it is recommended to look around. Do not let other people see the body when not wearing clothes. Just like sex education, it is not recommended to show limbs to other people [13]. Boys can be helped by fathers, while girls can be helped by mothers. This period is rarely taught when toilet training, even though so by teaching toilet training in Islam as well as teaching sex education. Children are taught to sit when they urinate. During this time the boy is standing when urinate but is healthier if done by sitting. Islam advocates this and also in accordance with the results of research sitting when urinating has many health and hygiene benefits [14].

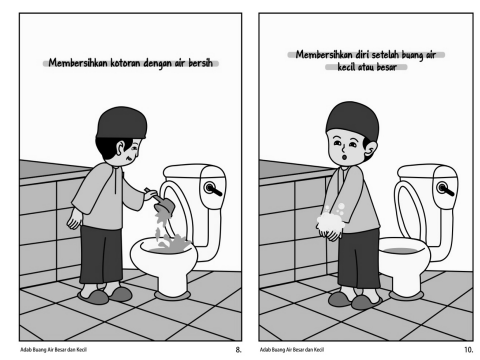

Fig. 4. How to Clean Up in Islamic View Point

Preschoolers when in school are taught to take responsibility for themselves. Therefore, cleaning urinate is also part of character development. After cleaning the urinate the child is taught to wash hands using soap so that no bacteria in the hand.

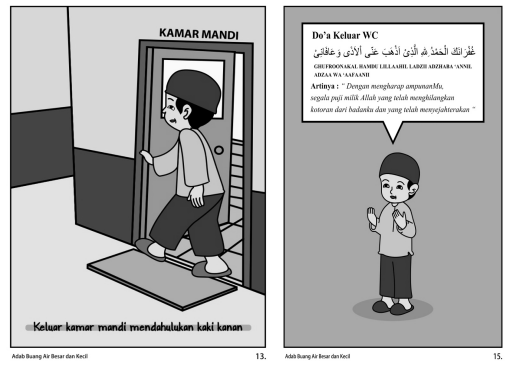

Fig. 5. How to Exit the Toilet in Islamic View Point

There is a difference by entering and exiting the toilet. Preschoolers are accustomed to entering with their left foot and out with their right foot. As with entering, when exiting the toilets, the child is accustomed to pray.

\section{The Validity of Guidebook Toilet Training}

The validity of guidebook toilet training is measured by trough expert validators. Validators are 4 teachers from 4 
school. The validated components namely: material, language, and image. The score of the material component is obtained at $81 \%$. While the language component score obtained $87 \%$. The last component image score increase at $85 \%$. From the results of this assessment, it can be concluded that the percentage of total validation results by media experts is valid and the next steps can be tested in the field.

\section{The Effectiveness of Guidebook Toilet Training}

The effectiveness of guidebook toilet training is measured by observing teacher activities, observing student activities and toilet training skills. Teacher activities scored $85 \%$ with very good categories. Student activities showed a score of $86 \%$ in the good category. Meanwhile, children's ability to understand each stage of toilet training in an Islamic perspective is $84 \%$. From the overall score, the average is $84 \%$. Therefore, in terms of effectiveness, it can be concluded that guidebook toilet training is very effective to be used in preschoolers.

Based on data analysis, the validity and effectiveness of guidebook toilet training show that the categories are feasible. The table below shows the quality of guidebook toilet training from an Islamic perspective with valid validity aspects, aspects of effectiveness are very effective. Finally, it can be concluded that guidebook toilet training is feasible and effective, making it easier for teachers to embed toilet training for preschoolers.

TABLE I. RECAPITULATION OF GUIDEBOOK TOILET TRAINING ASSESSMENT RESULT

\begin{tabular}{|c|c|c|c|c|c|}
\hline Toilet & & pect & $\%$ & Category & Resume \\
\hline Training & Validity & Material & 81 & Valid & Qualified \\
\hline Guidebook & & Language & 87 & & and \\
\hline For & & Picture & 85 & & Worthy \\
\hline $\begin{array}{l}\text { The } \\
\text { Independe }\end{array}$ & $\begin{array}{l}\text { Effective } \\
\text { ness }\end{array}$ & $\begin{array}{l}\text { Teacher } \\
\text { Activity }\end{array}$ & 85 & Effective & of use \\
\hline & & Preschoolers & 86 & & \\
\hline Character & & $\begin{array}{l}\text { Toilet } \\
\text { Training } \\
\text { Skills }\end{array}$ & 84 & & \\
\hline
\end{tabular}

Referring to the results of the comparison of valid values and effectiveness, it can be seen that guidebook toilet training with Islamic viewpoints can be developed properly. Therefore, it is accordance with the preschoolers that it can be easy to learn from the media [15]. Appropriate and attractive media accompany children's skills and habits.

\section{CONCLUSION}

Guidebook toilet training with an Islamic perspective is developed based on research procedures. The results of the development can be categorized as valid so that they are appropriate for preschoolers. Preschoolers can easily learn toilet training and Islam as well as guidebook toilet training. This makes teaching innovation an alternative. After completion of the development the next step is due diligence. The feasibility test is used to find out that the media is suitable for preschoolers. This guide has been used properly, making it easier for children to know the stage of toilet training in an Islamic perspective.
The trial was conducted in 4 schools, each representative school of 10 children. With the observation instrument, there are 3.4 observations from scale 4 . This shows that with the existence of a guide book the character of the child's discipline can be formed properly. Other research stated that the guidebook proved to facilitate beginners in learning [16].

Based on the results of the research, the suggestions for the sustainability of this research are: 1) Teachers can use guidebook toilet training as an alternative guideline from an Islamic perspective. 2) Parents can synergize with teachers in consistently forming children's independence during the toilet training process.

\section{REFERENCES}

[1] J. Rajan, "Effectiveness of Video Assisted Teaching Programme on Toilet Training of Toddlers among Parents in a Selected Rural Area in Shimla, Himachal Pradesh, India.," Indian J. Public Heal. Res. Dev., vol. 10 , no. 3, pp. 502-507, 2019.

[2] M. Simms, "Sequential Acquisition of Toilet-Training Skills: A Descriptive Study of Gender and Age Differences in Normal Children," 2002.

[3] S. Subagyo, A. Sulasih, and S. Widajati, "Hubungan antara motivasi stimulasi toilet training oleh ibu dengan keberhasilan toilet training pada anak prasekolah,” J. Penelit. Kesehat. Suara Forikes, vol. 2, no. 2, pp. 136-140, 2010.

[4] K. Dixon and H. Janks, "'My Fish Died and I Flushed Him Down the Toilet': Children Disrupt Preservice Teachers' Understandings of 'Appropriate' Picture Books for Young Children," Lit. Res. Theory, Method, Pract., vol. 67, no. 1, pp. 343-359, Nov. 2018.

[5] J. Nelsen, C. Erwin, and R. Duffy, Positive discipline for preschoolers : for their early years--raising children who are responsible, respectful, and resourceful.

[6] F. R. Cicero and A. Pfadt, "Investigation of a reinforcement-based toilet training procedure for children with autism," Res. Dev. Disabil., vol. 23, no. 5, pp. 319-331, Sep. 2002.

[7] D. Peck and D. Whitlow, Approaches to Personality Theory, Personality. New York: Routledge, 2019.

[8] W. Hulukati and M. Rahim, "The Effectiveness of Guidebooks to Improve Teachers' Competency in Teaching Gorontalo Local Language Learning for Early Childhood," in Proceedings of the 1st International Conference on Innovation in Education (ICoIE 2018), 2019.

[9] K. van Nunen, N. Kaerts, J.-J. Wyndaele, A. Vermandel, and G. Van Hal, "Parents' views on toilet training (TT)," J. Child Heal. Care, vol. 19 , no. 2, pp. 265-274, Jun. 2015.

[10] Illeris. Knud, Learning, Development and Education: From learning theory to education and ... - Knud Illeris - Google Books, 1st ed. New York: Routledge, 2016.

[11] P. Laverdure, M. McCann, H. McLoone, L. Moore, and L. Reed, "Developing quality indicators for school practice," J. Occup. Ther. Sch. Early Interv., vol. 12, no. 1, pp. 38-50, Jan. 2019.

[12] S. Kazi, E. Kazali, N. Makris, G. Spanoudis, and A. Demetriou, "Cognizance in cognitive development: A longitudinal study," Cogn. Dev., vol. 52, p. 100805, Oct. 2019.

[13] L. Bialystok and J. Wright, “'Just Say No': public dissent over sexuality education and the Canadian national imaginary," Discourse Stud. Cult. Polit. Educ., vol. 40, no. 3, pp. 343-357, May 2019.

[14] G. M. Assis, C. P. C. da Silva, and G. Martins, "Urotherapy in the treatment of children and adolescents with bladder and bowel dysfunction: a systematic review," J. Pediatr. (Rio. J)., Apr. 2019.

[15] S. Pasnik, Getting Ready to Learn: Creating Effective, Educational Children's Media - Shelley Pasnik - Google Books. 2019.

[16] R. J. Colvin, The Guidebook to Successful Safety Programming. CRC Press, 2018. 
